\title{
ddRAD sequencing-based identification of inter-genepool SNPs and association analysis in Brassica juncea
}

\author{
Jebi Sudan ${ }^{1,2}$, Ravinder Singh ${ }^{1 *}$ (D), Susheel Sharma ${ }^{1}$, Romesh K. Salgotra ${ }^{1}$, Varun Sharma ${ }^{3}$, Gurvinder Singh ${ }^{3}$,
} Indu Sharma ${ }^{3}$, Swarkar Sharma ${ }^{3}$, Surinder K. Gupta ${ }^{4}$ and Sajad Majeed Zargar ${ }^{5}$

\begin{abstract}
Background: Narrow genetic base, complex allo-tetraploid genome and presence of repetitive elements have led the discovery of single nucleotide polymorphisms (SNPs) in Brassica juncea (AABB; $2 n=4 x=36$ ) at a slower pace. Double digest RAD (ddRAD) - a genome complexity reduction technique followed by NGS was used to generate a total of 23 million paired-end reads from three genotypes each of Indian (Pusa Tarak, RSPR-01 and Urvashi) and Exotic (Donskaja IV, Zem 1 and EC287711) genepools.

Results: Sequence data analysis led to the identification of 10,399 SNPs in six genotypes at a read depth of 10x coverage among the genotypes of two genepools. A total of 44 hyper-variable regions (nucleotide variation hotspots) were also found in the genome, of which 93\% were found to be a part of coding genes/regions. The functionality of the identified SNPS was estimated by genotyping a subset of SNPs on MassARRAY ${ }^{\circledR}$ platform among a diverse set of $B$. juncea genotypes. SNP genotyping-based genetic diversity and population studies placed the genotypes into two distinct clusters based mostly on the place of origin. The genotypes were also characterized for six morphological traits, analysis of which revealed a significant difference in the mean values between Indian and Exotic genepools for six traits. The association analysis for six traits identified a total of 45 significant marker-trait associations on 11 chromosomes of A- and B- group of progenitor genomes.

Conclusions: Despite narrow diversity, the ddRAD sequencing was able to identify large number of nucleotide polymorphisms between the two genepools. Association analysis led to the identification of common SNPs/ genomic regions associated between flowering and maturity traits, thereby underscoring the possible role of common chromosomal regions-harboring genes controlling flowering and maturity in Brassica juncea.
\end{abstract}

Keywords: Single nucleotide polymorphisms (SNPs), Double digest-Restriction Associated DNA (dd-RAD), MassARRAY, Diversity analysis, Association mapping

\section{Background}

Brassica juncea commonly known as Indian mustard is an important oilseed crop in Indian subcontinent, northern China and eastern European countries. It is widely and extensively grown for seeds which yield an essential oil and condiment; however its young leaves are also used as vegetables or mixed with other salad greens. Brassica juncea has two diverse genepools: the Indian and the east

\footnotetext{
*Correspondence: rssandey@gmail.com

'School of Biotechnology, Sher-e-Kashmir University of Agricultural Sciences and Technology of Jammu, Jammu, J\&K, India

Full list of author information is available at the end of the article
}

European genepool (exotic) [1]. The east European genepool shows more diversity at the molecular level and has more yield potential while the Indian genepool has narrow genetic diversity with low yield potential $[2,3]$. In spite of the two morphological diverse pool, the crop experienced narrow genetic base that might be due to complex allotetraploid genome and domestication [4]. This narrow genetic base has hindered the process of germplasm enhancement as it reduces the chances of finding the diverse alleles of important agronomic traits for their introgression into elite germplasm [5].

(c) The Author(s). 2019 Open Access This article is distributed under the terms of the Creative Commons Attribution 4.0 International License (http://creativecommons.org/licenses/by/4.0/), which permits unrestricted use, distribution, and 
The genetic enhancement can be achieved by the transfer of alleles between exotic (European) and Indian genepools using either traditional plant breeding approaches or marker-assisted selection (MAS). While MAS require the identification and use of closely and tightly linked molecular markers with the trait of interest, association mapping does not need prior molecular mapping information and serves as an important tool to identify marker-trait associations on the basis of linkage disequilibrium (LD) only. Association analysis infers significant marker-trait associations by accounting for cosegregated (or co-transmission) alleles at different locations in a genome across a diverse set of mapping population [6], allows fine mapping of traits when used with a dense set of molecular markers. In oilseed Brassica spp. (B. juncea and B. napus) different types of molecular markers were employed with a combination of various models (GLM, Q, PCA and K) to figure out close relationship between various traits and markers. In most of the association mapping studies, the SSR markers were used for population studies due to their usefulness in population genetics inferences and these being highly informative when compared to biallelic markers [7]. However, the high heritability of SNPs also makes them an excellent indicator of genetic diversity and phylogeny in crop species with ancient genome duplications, such as in $B$. juncea. Various SSR-based genome-wide association mapping studies were conducted in $B$. juncea $[8,9]$ and $B$. napus [10-12] for various agronomically important traits. Moreover, Single Nucleotide Polymorphisms (SNPs) are also preferred for fine mapping studies, as reported in $B$. napus [13-17]. However no such study has been reported in B. juncea, mainly due to non-availability of SNP markers.

The discovery of SNPs in B. juncea has proceeded with a slower pace mainly due to its narrow genetic base, complex allotetraploid genome and highly repetitive regions $[18,19]$. The presence of two sub-genomes (A and B) makes SNP discovery and genotyping more difficult and troublesome due to the presence of both homologous and homoeologous DNA sequences. The process of SNP discovery is further complicated with duplications and triplications of $\mathrm{A}$ and $\mathrm{B}$ genomes due to polyploidization events [20]. To reduce the complexity of genomes, various genome reduction methods are available that uses a set of restriction enzymes and a particular selection process to sequence only the selected set of restriction fragments from multiple genotypes so as to do both the SNP discovery and genotyping at the same time. Advances in the bioinformatics software also support the rapid identification of true SNPs in the individuals.

In this study, a modified ddRADseq approach was followed to partially sequence genomes of six genotypes (three each from Indian and European genepool) of $B$. juncea for SNPs identification and genotyping. A bioinformatics pipeline was developed using tools available within CLC Genomics workbench for the detection of SNPs (Additional file 1: Figure S1). These SNPs were then used to assess the levels of molecular diversity and population structure among diverse set, and association mapping to identify significant marker-trait associations for six morphological traits.

\section{Results \\ ddRAD-library preparation and sequencing}

The microfluidics-based electrophoresis analyses of pooled library revealed that majority of fragments were represented in the range of 300 to 400 bases following size selection during library preparation (Additional file 1: Figure S2). The sequence-based barcoding followed by pooling and sequencing of six genotypes on Illumina HiSeq 2000 platform generated a total of about 23 million paired-end reads with an average of 3.83 million reads per genotypes. The mean read quality (Phred score) of six samples was 35.02 and about $89 \%$ reads had a Q score $>30$, indicating that most of the raw data were of good quality. The mean quality score of read 1 (R1) was slightly better than mean quality score of read 2 (R2) (Additional file 1: Table-S3). A slightly better quality of read 1 than 2 was attributed to the fact that the clones within each cluster in a flow cell had least damage due to repeated flushing of flow cell. This difference

Table 1 Summary of SNPs obtained in different genotypes

\begin{tabular}{|c|c|c|c|c|c|c|}
\hline Samples & $\begin{array}{l}\text { Total } \\
\text { Reads }\end{array}$ & $\begin{array}{l}\text { Total of reads after pre- } \\
\text { processing }\end{array}$ & $\begin{array}{l}\text { No. of reads } \\
\text { mapped }\end{array}$ & $\begin{array}{l}\text { Percent reads } \\
\text { mapped }\end{array}$ & $\begin{array}{l}\text { Percent uniquely mapped } \\
\text { reads }\end{array}$ & $\begin{array}{l}\text { SNPs at } 10 x \\
\text { coverage }\end{array}$ \\
\hline Zem 1 & $2,310,662$ & $2,291,416$ & $2,156,974$ & 94.13 & 83.60 & 1251 \\
\hline $\begin{array}{l}\text { Donskaja } \\
\text { IV }\end{array}$ & $2,361,678$ & $2,350,360$ & $2,201,589$ & 93.67 & 83.72 & 1273 \\
\hline $\begin{array}{l}\text { EC- } \\
287711\end{array}$ & $3,462,876$ & $3,437,132$ & $3,231,248$ & 94.03 & 84.19 & 1860 \\
\hline Pusa Tarak & $7,521,368$ & $7,438,610$ & $6,885,178$ & 92.56 & 83.25 & 2127 \\
\hline Urvashi & $3,731,080$ & $3,714,434$ & $3,504,568$ & 94.35 & 81.37 & 1898 \\
\hline RSPR-01 & $3,621,796$ & $3,597,428$ & $3,375,826$ & 93.84 & 82.50 & 1990 \\
\hline
\end{tabular}


Table 2 Hypervariable regions on different chromosome of Brassica juncea

\begin{tabular}{|c|c|c|c|c|c|c|}
\hline Chromosome & $\begin{array}{l}\text { Hyper-variable } \\
\text { region }\end{array}$ & $\begin{array}{l}\text { No. of } \\
\text { SNPs }\end{array}$ & $\begin{array}{l}\text { Frequency of } \\
\text { SNPs (per bp) }\end{array}$ & Predicted Protein & $\begin{array}{l}\text { Protein } \\
\text { Accession ID }\end{array}$ & $\begin{array}{l}\text { BlastX } \\
\text { e-value }\end{array}$ \\
\hline \multirow[t]{5}{*}{ A01 } & $\begin{array}{l}12,089,878 \text { to } \\
12,089,908\end{array}$ & 4 & 7.50 & SMAX1-LIKE 2 [Brassica rapa] & $\begin{array}{l}X P_{-} \\
009127888.1\end{array}$ & $\begin{array}{l}1.00 \mathrm{E}- \\
148\end{array}$ \\
\hline & $\begin{array}{l}13,064,396 \\
\text { to } 13064410\end{array}$ & 6 & 2.33 & Heptahelical transmembrane protein 2 [Brassica napus] & $\begin{array}{l}X P_{-} \\
013730768.1\end{array}$ & $\begin{array}{l}2.00 \mathrm{E}- \\
040\end{array}$ \\
\hline & $\begin{array}{l}23,525,876 \text { to } \\
23,525,886\end{array}$ & 4 & 2.50 & $\begin{array}{l}\text { Farnesyl transferase/ geranylgeranyl transferase type-1 subunit } \\
\text { alpha } \\
\text { [Brassica rapa] }\end{array}$ & $\begin{array}{l}X P_{-} \\
009147222.1\end{array}$ & $\begin{array}{l}2.00 \mathrm{E}- \\
029\end{array}$ \\
\hline & $\begin{array}{l}37,133,315 \text { to } \\
37,133,336\end{array}$ & 5 & 4.20 & $\begin{array}{l}\text { Uncharacterized protein LOC106335203 } \\
\text { [Brassica oleracea] }\end{array}$ & $\begin{array}{l}X P_{-} \\
013629110.1\end{array}$ & $\begin{array}{l}1.00 \mathrm{E}- \\
042\end{array}$ \\
\hline & $\begin{array}{l}38,650,911 \text { to } \\
38,650,931\end{array}$ & 4 & 5.00 & $\begin{array}{l}\text { Calcium-binding EF-hand family protein } \\
\text { (Arabidopsis thaliana) }\end{array}$ & $\begin{array}{l}N_{-} \\
001332476.1\end{array}$ & $\begin{array}{l}6.00 \mathrm{E}- \\
056\end{array}$ \\
\hline \multirow[t]{2}{*}{ A02 } & $\begin{array}{l}2,398,121 \\
\text { to } 2398162\end{array}$ & 6 & 6.83 & No significant hit & & \\
\hline & $\begin{array}{l}14,416,494 \text { to } \\
14,416,505\end{array}$ & 5 & 2.20 & Uncharacterized protein & RQM01316.1 & $\begin{array}{l}3.00 \mathrm{E}- \\
030\end{array}$ \\
\hline \multirow[t]{2}{*}{ A03 } & $\begin{array}{l}25,641,944 \text { to } \\
25,641,977\end{array}$ & 7 & 4.71 & Hypothetical protein DY000_00001393 [Brassica cretica] & RQL75529.1 & $\begin{array}{l}1.00 \mathrm{E}- \\
009\end{array}$ \\
\hline & $\begin{array}{l}42,576,172 \text { to } \\
43,014,367\end{array}$ & 9 & 21.66 & Uncharacterized protein LOC106363406 [Brassica napus] & $\begin{array}{l}X P_{-} \\
013658605.1\end{array}$ & $\begin{array}{l}3.00 \mathrm{E}- \\
079\end{array}$ \\
\hline \multirow[t]{2}{*}{ A04 } & $\begin{array}{l}8,377,252 \text { to } 8 \\
377,288\end{array}$ & 10 & 3.60 & Uncharacterized protein LOC106360747 [Brassica napus] & $\begin{array}{l}X P_{-} \\
013655857.1\end{array}$ & $\begin{array}{l}3.00 \mathrm{E}- \\
113\end{array}$ \\
\hline & $\begin{array}{l}14,731,032 \text { to } \\
14,908,156\end{array}$ & 4 & 31.00 & Transcription factor MYC2 [Brassica rapa) & $\begin{array}{l}X P_{-} \\
009151447.1\end{array}$ & $\begin{array}{l}8.00 \mathrm{E}- \\
166\end{array}$ \\
\hline \multirow[t]{5}{*}{ A05 } & $\begin{array}{l}1,588,930 \text { to } 1 \\
588,970\end{array}$ & 5 & 8.00 & Polygalacturonase-like [Brassica oleracea] & $\begin{array}{l}X P_{-} \\
013633855.1\end{array}$ & $\begin{array}{l}4.00 \mathrm{E}- \\
084\end{array}$ \\
\hline & $\begin{array}{l}19,985,702 \text { to } \\
19,985,780\end{array}$ & 5 & 15.60 & BnaC08g47040D [Brassica napus] & CDY43697.1 & $\begin{array}{l}8.00 \mathrm{E}- \\
054\end{array}$ \\
\hline & $\begin{array}{l}21,938,359 \text { to } \\
21,938,393\end{array}$ & 6 & 5.66 & $\begin{array}{l}\text { Probable LRR receptor-like serine/threonine-protein kinase } \\
\text { At4g36180 [Brassica napus] }\end{array}$ & $\begin{array}{l}X P_{-} \\
013716480.1\end{array}$ & $\begin{array}{l}5.00 \mathrm{E}- \\
166\end{array}$ \\
\hline & $\begin{array}{l}27,265,183 \text { to } \\
27,265,231\end{array}$ & 5 & 9.60 & Hypothetical protein BRARA_K01418 [Brassica rapa] & RIA04352.1 & $\begin{array}{l}1.00 \mathrm{E}- \\
019\end{array}$ \\
\hline & $\begin{array}{l}35,529,249 \text { to } \\
35,529,274\end{array}$ & 5 & 5.00 & $\begin{array}{l}\text { Cis-phytoenedesaturase, chloroplastic/chromoplastic [Brassica } \\
\text { napus] }\end{array}$ & $\begin{array}{l}X P_{-} \\
013750375.2\end{array}$ & $\begin{array}{l}9.00 \mathrm{E}- \\
065\end{array}$ \\
\hline \multirow[t]{3}{*}{ A06 } & $\begin{array}{l}11,405,649 \text { to } \\
11,405,684\end{array}$ & 5 & 7.00 & BnaA06g 16240D [Brassica napus] & CDY08102.1 & $\begin{array}{l}4.00 \mathrm{E}- \\
077\end{array}$ \\
\hline & $\begin{array}{l}31,624,120 \text { to } \\
31,624,155\end{array}$ & 6 & 5.83 & $\begin{array}{l}\text { Hypothetical protein } \\
\text { RQL85806.1 }\end{array}$ & RQL85806.1 & $\begin{array}{l}2.00 \mathrm{E}- \\
097\end{array}$ \\
\hline & $\begin{array}{l}36,377,825 \text { to } \\
36,377,860\end{array}$ & 5 & 7.00 & Uncharacterized protein LOC106401547 [Brassica napus] & $\begin{array}{l}X P_{-} \\
022543736.1\end{array}$ & $\begin{array}{l}5.00 \mathrm{E}- \\
084\end{array}$ \\
\hline \multirow[t]{2}{*}{ A07 } & $\begin{array}{l}13,947,963 \text { to } \\
13,948,008\end{array}$ & 5 & 9.00 & Unnamed protein product (Brassica rapa) & VDC98355.1 & $\begin{array}{l}2.00 \mathrm{E}- \\
072\end{array}$ \\
\hline & $\begin{array}{l}16,375,261 \text { to } \\
16,375,275\end{array}$ & 5 & 2.80 & Uncharacterized protein LOC103829921 [Brassica rapa] & $\begin{array}{l}X P_{-} \\
009103854.1\end{array}$ & $\begin{array}{l}6.00 \mathrm{E}- \\
034\end{array}$ \\
\hline \multirow[t]{5}{*}{ B01 } & $\begin{array}{l}24,425,289 \text { to } \\
24,425,343\end{array}$ & 10 & 5.40 & $\begin{array}{l}\text { Uncharacterized abhydrolase domain-containing protein DDB_ } \\
\text { G0269086-like [Brassica rapa] }\end{array}$ & & $\begin{array}{l}4.00 \mathrm{E}- \\
090\end{array}$ \\
\hline & $\begin{array}{l}33,418,235 \text { to } \\
33,418,261\end{array}$ & 5 & 5.20 & Unnamed protein product [Brassica rapa] & VDC90843.1 & $\begin{array}{l}2.00 \mathrm{E}- \\
094\end{array}$ \\
\hline & $\begin{array}{l}51,944,663 \\
\text { to } 51944714\end{array}$ & 6 & 8.50 & Uncharacterized protein LOC106308810 [Brassica oleracea] & $\begin{array}{l}X P_{-} \\
013601383.1\end{array}$ & $\begin{array}{l}4.00 \mathrm{E}- \\
098\end{array}$ \\
\hline & $\begin{array}{l}53,225,827 \text { to } \\
53,225,840\end{array}$ & 5 & 2.60 & Homocysteine S-methyltransferase 2 [Brassica napus] & $\begin{array}{l}X P_{-} \\
013712093.1\end{array}$ & $\begin{array}{l}1.00 \mathrm{E}- \\
040\end{array}$ \\
\hline & $\begin{array}{l}53,650,933 \text { to } \\
53,650,972\end{array}$ & 5 & 7.80 & Hypothetical protein DY000_00003913 [Brassica cretica] & RQL77992.1 & $\begin{array}{l}4.00 \mathrm{E}- \\
076\end{array}$ \\
\hline
\end{tabular}


Table 2 Hypervariable regions on different chromosome of Brassica juncea (Continued)

\begin{tabular}{|c|c|c|c|c|c|c|}
\hline Chromosome & $\begin{array}{l}\text { Hyper-variable } \\
\text { region }\end{array}$ & $\begin{array}{l}\text { No. of } \\
\text { SNPs }\end{array}$ & $\begin{array}{l}\text { Frequency of } \\
\text { SNPs (per bp) }\end{array}$ & Predicted Protein & $\begin{array}{l}\text { Protein } \\
\text { Accession ID }\end{array}$ & $\begin{array}{l}\text { BlastX } \\
\text { e-value }\end{array}$ \\
\hline \multirow[t]{2}{*}{$\mathrm{B} 02$} & $\begin{array}{l}6,040,643 \text { to } 6 \\
040,712\end{array}$ & 11 & 6.27 & Unnamed protein product [Brassica rapa] & VDD17261.1 & $\begin{array}{l}4.00 \mathrm{E}- \\
004\end{array}$ \\
\hline & $\begin{array}{l}14,431,647 \text { to } \\
14,431,685\end{array}$ & 5 & 7.60 & No significant hit & & \\
\hline \multirow[t]{5}{*}{ B04 } & $\begin{array}{l}18,482,342 \text { to } \\
18,482,397\end{array}$ & 4 & 13.75 & $\begin{array}{l}\text { Uncharacterized protein At3g60930, chloroplastic-like [Brassica } \\
\text { napus] }\end{array}$ & $\begin{array}{l}X P_{-} \\
022567433.1\end{array}$ & $\begin{array}{l}7.00 \mathrm{E}- \\
009\end{array}$ \\
\hline & $\begin{array}{l}29,636,717 \text { to } \\
29,636,764\end{array}$ & 8 & 5.87 & BnaA02g16800D [Brassica napus] & CDY49126.1 & $\begin{array}{l}8.00 \mathrm{E}- \\
035\end{array}$ \\
\hline & $\begin{array}{l}46,447,876 \text { to } \\
46,447,889\end{array}$ & 6 & 2.16 & hypothetical protein DY000_00030648 [Brassica cretica] & RQM04119.1 & $\begin{array}{l}4.00 \mathrm{E}- \\
034\end{array}$ \\
\hline & $\begin{array}{l}52,254,291 \text { to } \\
52,254,327\end{array}$ & 5 & 7.20 & ras-related protein $\mathrm{RABD} 2 \mathrm{c}$ isoform $\mathrm{X} 1$ [Brassica rapa] & $\begin{array}{l}X P_{-} \\
009130704.1\end{array}$ & $\begin{array}{l}1.00 \mathrm{E}- \\
154\end{array}$ \\
\hline & $\begin{array}{l}53,387,066 \text { to } \\
53,387,117\end{array}$ & 5 & 10.20 & $\begin{array}{l}\text { uncharacterized mitochondrial protein AtMg00810-like [Brassica } \\
\text { oleracea var. oleracea] }\end{array}$ & $\begin{array}{l}X P_{-} \\
013601341.1\end{array}$ & $\begin{array}{l}2.00 \mathrm{E}- \\
138\end{array}$ \\
\hline \multirow[t]{3}{*}{ B05 } & $\begin{array}{l}12,937,005 \text { to } \\
12,937,060\end{array}$ & 5 & 10.00 & hypothetical protein MANES_08G079400 [Manihot esculenta] & OAY43565.1 & $\begin{array}{l}3.00 \mathrm{E}- \\
014\end{array}$ \\
\hline & $\begin{array}{l}68,021,640 \text { to } \\
68,021,664\end{array}$ & 7 & 3.42 & caffeic acid 3-O-methyltransferase-like [Raphanus sativus] & $\begin{array}{l}X P_{-} \\
018461242.1\end{array}$ & $\begin{array}{l}4.00 \mathrm{E}- \\
058\end{array}$ \\
\hline & $\begin{array}{l}80,717,492 \text { to } \\
80,717,516\end{array}$ & 7 & 3.43 & glutathione S-transferase T3-like [Brassica oleracea var. oleracea] & $\begin{array}{l}X P_{-} \\
013639324.1\end{array}$ & $\begin{array}{l}3.00 \mathrm{E}- \\
107\end{array}$ \\
\hline \multirow[t]{2}{*}{ B06 } & $\begin{array}{l}1,593,067 \text { to } 1 \\
593,109\end{array}$ & 11 & 3.82 & BnaC04g03580D [Brassica napus] & CDY17861.1 & $\begin{array}{l}8.00 \mathrm{E}- \\
011\end{array}$ \\
\hline & $\begin{array}{l}2,770,283 \text { to } 2 \\
770,305\end{array}$ & 5 & 4.40 & uncharacterized acetyltransferase At3g50280 [Raphanus sativus] & $\begin{array}{l}X P_{-} \\
018434505.1\end{array}$ & 0 \\
\hline B07 & $\begin{array}{l}23,121,758 \\
\text { to } 23121773\end{array}$ & 5 & 3.00 & uncharacterized protein LOC108830363 [Raphanus sativus] & $\begin{array}{l}X P_{-} \\
018459472.1\end{array}$ & $\begin{array}{l}1.00 \mathrm{E}- \\
150\end{array}$ \\
\hline B08 & $\begin{array}{l}15,772,508 \text { to } \\
15,772,583\end{array}$ & 10 & 7.50 & $\begin{array}{l}\text { probable LRR receptor-like serine/threonine-protein kinase } \\
\text { At4g36180 isoform X1 [Raphanus sativus] }\end{array}$ & $\begin{array}{l}X P_{-} \\
018460684.1\end{array}$ & $\begin{array}{l}2.00 \mathrm{E}- \\
074\end{array}$ \\
\hline \multirow[t]{2}{*}{ B09 } & $\begin{array}{l}29,343,310 \text { to } \\
29,343,368\end{array}$ & 8 & 7.25 & No significant hit & NA & NA \\
\hline & $\begin{array}{l}32,306,181 \text { to } \\
32,306,211\end{array}$ & 6 & 5.00 & U-box domain-containing protein 9-like [Brassica napus] & $\begin{array}{l}X P_{-} \\
013684649.1\end{array}$ & $\begin{array}{l}4.00 \mathrm{E}- \\
055\end{array}$ \\
\hline \multirow[t]{2}{*}{ B10 } & $\begin{array}{l}63,679,073 \text { to } \\
63,679,088\end{array}$ & 6 & 2.50 & uncharacterized protein LOC106424516 [Brassica napus] & $\begin{array}{l}X P_{-} \\
013720737.1\end{array}$ & $\begin{array}{l}1.00 \mathrm{E}- \\
107\end{array}$ \\
\hline & $\begin{array}{l}69,805,021 \text { to } \\
69,805,080\end{array}$ & 7 & 8.42 & uncharacterized protein LOC106361641 [Brassica napus] & $\begin{array}{l}X P_{-} \\
02549137.1\end{array}$ & 0 \\
\hline
\end{tabular}

in quality scores between two reads is also attributed to phasing errors [21].

\section{Sequence analysis and SNP identification}

After trimming for low quality sequences, the processed reads were assembled into contigs followed by their alignment to the reference genome of B. juncea (GenBank: LFQT00000000) using default parameters and about $92-94 \%$ reads were mapped to the reference genome. The mapping percentages for individual samples ranged from 92.56 (Zem 1) to 94.35 (Donskaja IV). Out of all the mapped reads, more than $80 \%$ reads mapped uniquely to a single locus (Table 1 ).

The alignments of contig sequences to the reference genome were used for the identification of SNPs using
Probabilistic variant detection method. After filtering for homoeologs, a total of 10,399 single nucleotide variants with a depth of at least 10 reads were found to be distributed among six genotypes.

\section{SNPs in hyper-variable regions and protein prediction}

The stringent condition followed during size selection and SNPs identification has led to the retrieval of less number of SNP markers in the genotypes. Although the SNPs were distributed on all the chromosomes there were regions in various chromosomes with high frequency of SNPs as compared to the other regions referred to as hyper-variable regions or SNP hotspots. In all, a total of 44 hypervariable regions or hotspots of SNPs were found on all chromosomes except A08 and 
(a)
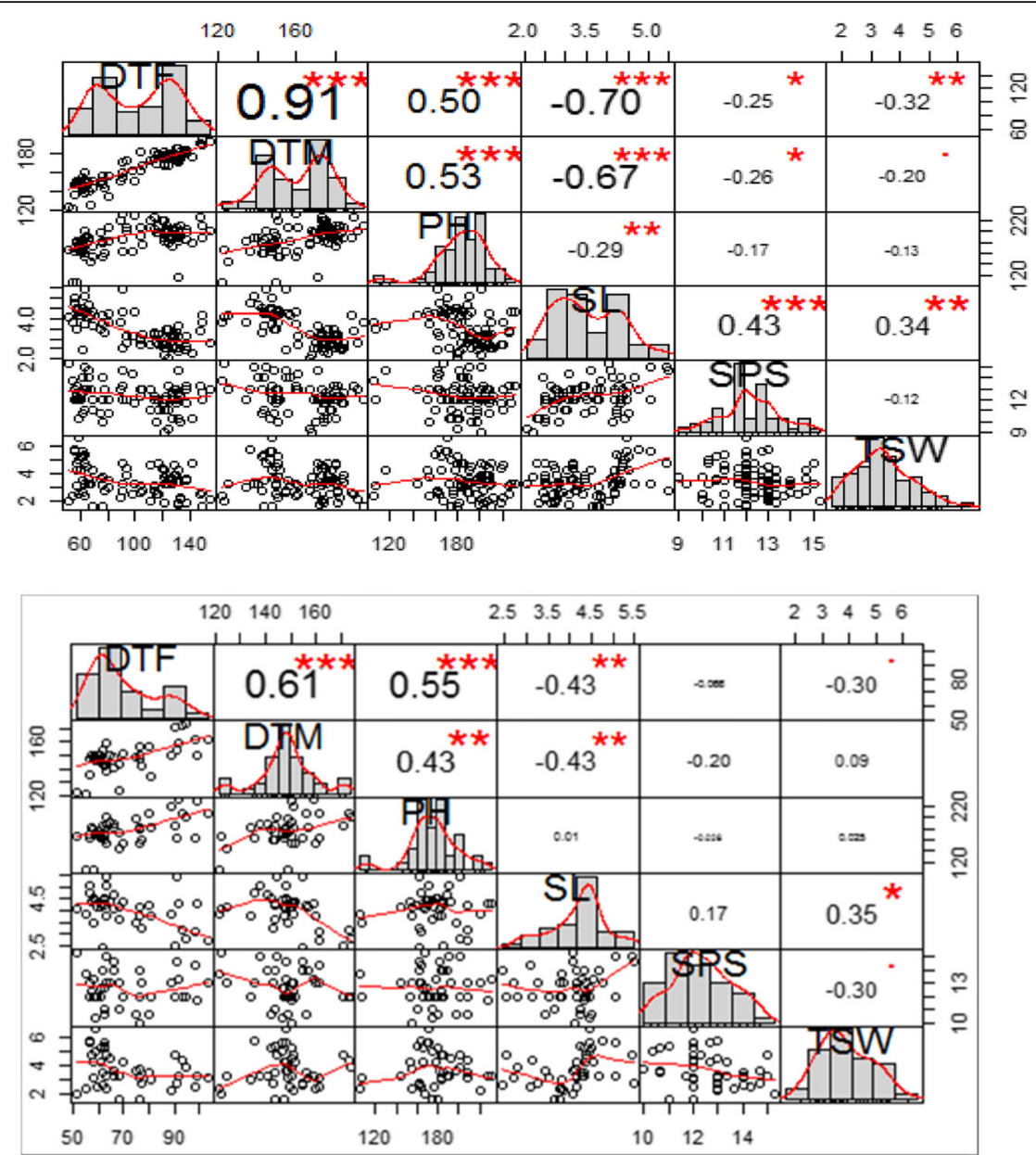

(b)

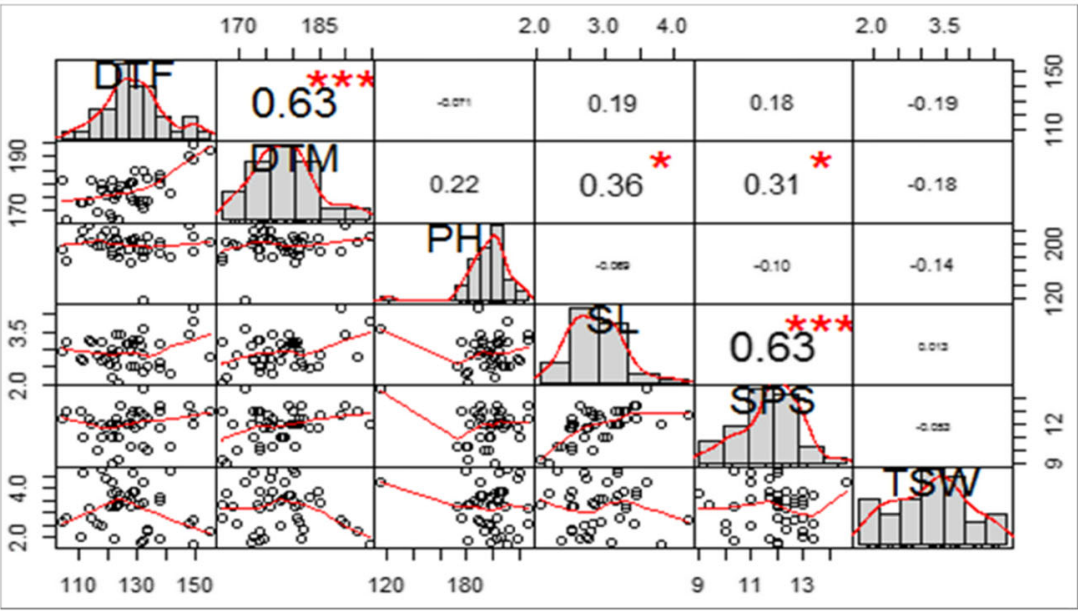

Fig. 1 Correlation chart for six morphological traits: (a) using 80 genotypes of Brassica juncea of Indian and European genepools indicating bimodal distribution for DTF and DTM (b) of genotypes of Indian genepool only, and (c) of genotypes of European genepool only

B03. Total number of hypervariable regions on these chromosomes ranged from one to five and total number of SNPs in these regions ranged from four to eleven. A
BlastX analysis of the hyper-variable sequences identified that nearly $93.2 \%$ of these hypervariable regions found to be part of coding sequences (Table 2). 
Table 3 Average values of important traits and their $p$-values for significance of difference of means between two genepools

\begin{tabular}{|c|c|c|c|c|}
\hline \multirow[t]{2}{*}{ Trait } & \multicolumn{2}{|l|}{ Mean value } & \multirow{2}{*}{$\begin{array}{l}\text { Absolute } \\
\text { difference } \\
\text { of means }\end{array}$} & \multirow{2}{*}{$\begin{array}{l}\text { P-value } \\
\text { (t-test) }\end{array}$} \\
\hline & Indian genepool & European genepool & & \\
\hline Days to emergence (in days) & 7.67 & 8.38 & 0.71 & 2.23E-05 \\
\hline Days to flowering (in days) & 70.98 & 127.02 & 56.04 & $2.56 \mathrm{E}-33$ \\
\hline Days to maturity (in days) & 148.48 & 177.81 & 29.33 & 7.22E-25 \\
\hline Plant height (in cms) & 177.31 & 197.17 & 19.86 & 5.26E-05 \\
\hline Siliqua length (in cms) & 4.05 & 2.93 & 1.12 & $1.06 \mathrm{E}-13$ \\
\hline Seeds per siliqua & 12.67 & 11.90 & 0.77 & 0.00356 \\
\hline Thousand seed weight (in gms) & 3.72 & 3.21 & 0.51 & 0.0133 \\
\hline
\end{tabular}

\section{Morphological analysis of diverse genepools}

The diverse core set of $B$. juncea consisting of 80 genotypes was characterized for various growth and yield traits under two locations in 2015-16 and 2016-17. The data collected over two locations was used to calculate mean values for individual genotypes for days to flowering (DTF), days to maturity (DTM), plant height (PH), siliqua length (SL), seeds per siliqua (SPS) and thousand seed weight (TSW). An analysis of chart correlation for various traits indicated that except DTF and DTM, all the traits were normally distributed in the diverse core set (Fig. 1). In view of the bi-modal distribution for DTF and DTM, the average values for these two traits were used to classify the diverse core set into two genepools namely European (Exotic) and Indian genepools. The individual chart correlation for two genepools indicated normal distribution for all the traits including DTF and DTM.

Among two genepools, the traits had divergent correlations with other traits. In Indian genepool, DTF had high correlation with all traits except SPS; while DTF in European genes had significant correlation with DTM only. The DTM in Indian genepool was significantly correlated with PH (0.43) and SL (-0.43); however the same trait did not show any significant correlation with $\mathrm{PH}$ and a positive significant correlation with SL (0.36) and SPS (0.31). PH was significantly correlated with DTF and DTM in Indian genepool but not in European. SL was negatively correlated with both DTF and interestingly with DTM; and positively with TSW in Indian genepool. However, SL had significant but opposite correlation with DTM in European genepool. SPS was not correlated with any of the yield traits in Indian genepool, but was significantly correlated with SL and DTM. In both the genepools, TSW was not significantly correlated with any of the traits but SL in European. The ttest for means for two genepools indicated that the average values for two genepools were significantly different. The $p$-values for Student's t-test indicated that the difference in mean values of all the traits among two genepools was highly significant (Table 3 ).

\section{Diversity analysis and population structure using SNP markers}

A total of 61 SNP markers widely distributed across the $B$. juncea genome were used for the characterization of core set to develop diversity profile of 80 genotypes. Out of 61 markers, 48 SNP markers were found to be polymorphic. Due to biallelic nature of the marker, a total of 98 alleles were amplified (Table 4). The minor allele frequency ranged from 0.00 to 0.46 with an average of 0.16 . The gene diversity and heterozygosity also identified a remarkable degree of variability among the genotypes. The gene diversity value ranged from 0.013 to 0.49 and heterozygosity value ranged from 0.012 to 0.69 with an average of 0.16. PIC (Polymorphism Information Content) values in the present study were found to have ranged from 0.012 to 0.371 with an average of 0.19 .

The population structure of 80 genotypes was estimated under the Hardy-Weinberg Equilibrium by using STRUCTURE V2.3.4 software. Based on the maximum likelihood and delta $K(\Delta \mathrm{K})$ values, the number of optimal groups was identified as two (Fig. 2). A dendrogram constructed using marker allelic data also grouped 80 genotypes into two distinct clusters and the local selection from Turkey forms a separate group. All 80 genotypes were grouped into three major clusters in which cluster I, II and III each contained 29, 50 and 1 genotypes, respectively. Cluster I and II also shows the grouping of genotypes into sub-clusters (Fig. 3). The clustering indicated the ability of SNP markers to group together the related genotypes from a geographical region with high level of accuracy. Cluster I consists of genotype mostly form Indian subcontinent and cluster II consists of exotic genotypes. However, some of the exotic genotypes (EC287711, EC206712, EC491584, EC699038-II and EC699059) were grouped along with the Indian genotypes which may be due to the fact that the allelic composition among these genotypes was identical at some of the loci that were considered in the present study. It may be possible to further refine their grouping patterns by characterization them at greater 
Table 4 Summary of SNP markers used for genetic diversity analysis

\begin{tabular}{|c|c|c|c|c|}
\hline Marker & Minor Allele frequency & Gene diversity & Heterozygosity & PIC \\
\hline A01_15062568 & 0.0733 & 0.1359 & 0.0667 & 0.1267 \\
\hline A01_1808370 & 0.3182 & 0.4339 & 0.0649 & 0.3398 \\
\hline A01_2139728 & 0.0385 & 0.0740 & 0.0769 & 0.0712 \\
\hline A01_6850903 & 0.2013 & 0.3216 & 0.4026 & 0.2699 \\
\hline A02_11859880 & 0.0130 & 0.0256 & 0.0000 & 0.0253 \\
\hline A02_24062658 & 0.3354 & 0.4458 & 0.6709 & 0.3465 \\
\hline A02_6601611 & 0.1795 & 0.2945 & 0.1538 & 0.2512 \\
\hline A03_20651981 & 0.3158 & 0.4321 & 0.1579 & 0.3388 \\
\hline A03_235511 & 0.0921 & 0.1672 & 0.1842 & 0.1533 \\
\hline A03_8547652 & 0.4423 & 0.4933 & 0.2436 & 0.3716 \\
\hline A04_17601178 & 0.3333 & 0.4444 & 0.0870 & 0.3457 \\
\hline A04_22058882 & 0.0068 & 0.0136 & 0.0137 & 0.0135 \\
\hline A05_77262 & 0.1597 & 0.2684 & 0.1528 & 0.2324 \\
\hline A06_13980299 & 0.0986 & 0.1777 & 0.0563 & 0.1619 \\
\hline A06_23478761 & 0.1800 & 0.2952 & 0.0933 & 0.2516 \\
\hline A06_6796237 & 0.3654 & 0.4638 & 0.0385 & 0.3562 \\
\hline A06_7120163 & 0.1159 & 0.2050 & 0.0580 & 0.1840 \\
\hline A07_11271 & 0.1776 & 0.2922 & 0.1184 & 0.2495 \\
\hline A07_15075686 & 0.2697 & 0.3940 & 0.3816 & 0.3164 \\
\hline A07_27294906 & 0.0455 & 0.0868 & 0.0390 & 0.0830 \\
\hline A08_19948782 & 0.0570 & 0.1074 & 0.0633 & 0.1017 \\
\hline A08_26316831 & 0.1859 & 0.3027 & 0.2436 & 0.2569 \\
\hline A08_3122114 & 0.0461 & 0.0879 & 0.0921 & 0.0840 \\
\hline A09_14703423 & 0.2961 & 0.4168 & 0.5921 & 0.3299 \\
\hline A09_21038191 & 0.3651 & 0.4636 & 0.3175 & 0.3561 \\
\hline A09_2675557 & 0.1169 & 0.2064 & 0.2338 & 0.1851 \\
\hline A09_53225827 & 0.0506 & 0.0961 & 0.0253 & 0.0915 \\
\hline A10_7119156 & 0.0316 & 0.0613 & 0.0127 & 0.0594 \\
\hline B01_31415063 & 0.2603 & 0.3851 & 0.1096 & 0.3109 \\
\hline B01_4700624 & 0.0132 & 0.0260 & 0.0263 & 0.0256 \\
\hline B02_14715231 & 0.1646 & 0.2750 & 0.1519 & 0.2372 \\
\hline B02_1692560 & 0.2500 & 0.3750 & 0.0897 & 0.3047 \\
\hline B02_372260 & 0.3882 & 0.4750 & 0.1974 & 0.3622 \\
\hline B03_11917496 & 0.0600 & 0.1128 & 0.0400 & 0.1064 \\
\hline B03_3641145 & 0.1842 & 0.3006 & 0.3684 & 0.2554 \\
\hline B03_36694310 & 0.0949 & 0.1718 & 0.0633 & 0.1571 \\
\hline B03_7368186 & 0.0063 & 0.0126 & 0.0127 & 0.0125 \\
\hline B04_1593069 & 0.0135 & 0.0267 & 0.0270 & 0.0263 \\
\hline B04_20687623 & 0.2273 & 0.3512 & 0.0909 & 0.2896 \\
\hline B04_27793042 & 0.2368 & 0.3615 & 0.3684 & 0.2962 \\
\hline B05_329343 & 0.1948 & 0.3137 & 0.2338 & 0.2645 \\
\hline B06_1587764 & 0.3467 & 0.4530 & 0.6933 & 0.3504 \\
\hline B06_18644772 & 0.2658 & 0.3903 & 0.5316 & 0.3141 \\
\hline B06_9741730 & 0.3333 & 0.4444 & 0.1600 & 0.3457 \\
\hline
\end{tabular}


Table 4 Summary of SNP markers used for genetic diversity analysis (Continued)

\begin{tabular}{lllll}
\hline Marker & Minor Allele frequency & Gene diversity & Heterozygosity & PIC \\
\hline B07_19090096 & 0.4675 & 0.4979 & 0.9351 & 0.3739 \\
B08_189749 & 0.1582 & 0.2664 & 0.1139 & 0.2309 \\
B08_72248023 & 0.0584 & 0.1101 & 0.1169 & 0.1040 \\
B08_7286923 & 0.3377 & 0.4557 & 0.0779 & 0.3631 \\
Mean & 0.1660 & 0.2410 & 0.1676 & 0.1978 \\
\hline
\end{tabular}

number of genetic loci as compared to the small subset of 61 SNP markers.

\section{Association mapping analysis}

The association analysis to identify markers associated with six yield contributing traits was carried out using a set of 61 SNPs uniformly distributed across the all the chromosomes of $B$. juncea. In order to determine the true marker-trait associations, we used both $p$ values and marker $r^{2}$ value for association and only those significant associations are considered where the $p$ values were $<10^{-6}$. Out of $61 \mathrm{SNPs}$ used, $18 \mathrm{SNPs}$ were involved in 45 significant marker-trait associations for six different traits (Table 5). These associations were localized on 11 out of 18 chromosomes of $B$. juncea with a total of 23 marker-trait associations of A-genome and 22 of B-genome chromosomes. A highest of 16 associations were found for DTF, followed by 13 for SL, 12 for DTM, 2 for TSW and 1 each for SPS and PH. Almost all SNPs, except two - one each on A07 and B02, were involved in multiple associations with different traits. A lone SNP marker on B04 was found to be associated with four different traits; eight SNPs were found to be associated with three different traits followed by associations of six SNPs with two traits each. The SNP markers involved in associations with DTF, DTM and SL, were distributed on both A- and B-genome chromosomes, and these associations were found on multiple chromosomes. The SNPs for SPS, PH and TSW were found to be distributed on single chromosomes only of B-genome. The $p$-value for all the associations was less than the threshold value as determined by p-value (0.015) of false discovery rate. The $p$ values for all the associations ranged from 1.26E-05 to $1.15 \mathrm{E}-18$ and the phenotypic variance contribution $\left(\mathrm{r}^{2}\right)$ ranged from 0.20 to 0.89 .

\section{Discussion}

A plethora of molecular marker-based studies have led to a greater understanding of the genetic make-up of Brassica species. SNP markers have been vital for the (fine) mapping of genes of agronomic importance with the goal of implementing marker-assisted breeding of elite crop cultivars. SNPs are distributed far more frequently in a genome and have been used to develop high-density molecular genetic maps and fine mapping of a region of interest. The abundance of SNPs in genome, low mutation rate and high heritability offsets the disadvantage of bi-allelism. SNPs are found randomly distributed throughout the genome in both repetitive and non-repetitive regions, however those present in the genic/non-repetitive regions are of keen importance. The presence of orthologous regions among the progenitors of allopolyploid genome adds an extra layer of genome complexity in addition to repetitive elements. However, recent advances in reducing the genome complexity coupled with NGS technologies have been highly successful to develop genome-wide SNPs in crops.

In the current study, a pair of restriction enzyme digestion (MseI and $S a c \mathrm{I}$ ) was used for ddRAD sequencing of unique regions of $B$. juncea. The similar technique of genome complexity reduction has also been employed in several crops [22-24] animal [25] and insects [26, 27] species. A number of modifications of this technique have been proposed. In case of other polyploid crop (cotton), GR-RSC (Genome Reduction-Restriction Site Conservation) technique was followed and a combination of $E c o$ RI and $B f a$ I restriction enzymes were used with a size selection between 450 and 600 bp [28] while another study preferred to use a combination of EcoRI and $M s p$ I with size selection around 200-400 bp [25].

Following sequencing of genotypes, a total of $2300 \mathrm{MB}$ paired-end sequence data were obtained from six $B$. juncea genotypes with an average of $383.33 \mathrm{MB}$ from each genotype. Similarly an average of $147.3 \mathrm{MB}$ data was obtained following dd-RAD sequencing of rice [29]. Considering the genome size of B. juncea of $955 \mathrm{MB}$ and the single read sequencing data from six genotypes of 1150 $\mathrm{MB}$, the individual genotype represent an average of $20 \%$ of the whole genome and thus, reducing the genome complexity by nearly five folds. Another study on Brassica species reported a reduction of nearly similar genome portion following ddRAD [30]. The mean quality score for both reads ranged from 34.63 to 35.40 and $90 \%$ sequence data with a $\mathrm{Q}$ score of at least 30 indicated that the sequencing reads were of high quality for reference genome alignment and SNP identification. Similar quality scores for high throughput sequencing runs have been reported with different genome complexity reduction method (SLAF-seq) in tea [31]. Due to high Q 


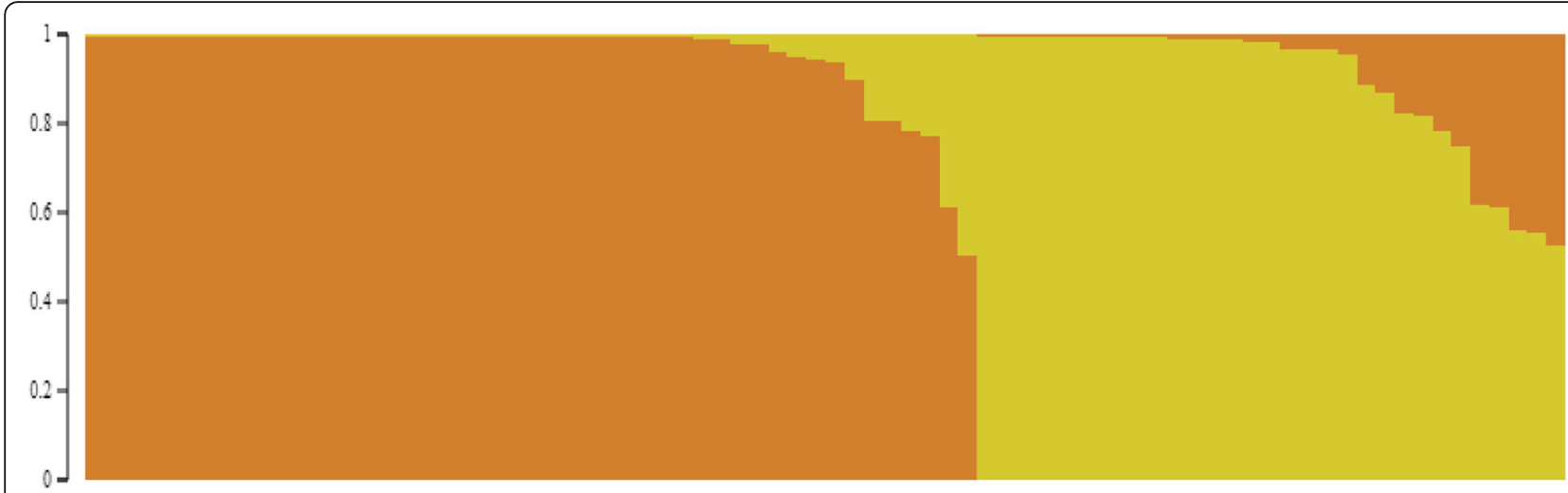

Fig. 2 STRUCTURE analysis indicated genotypes grouping into two sub-populations based on membership coefficients indicated on vertical coordinate

score, a large proportion (nearly $83 \%$ ) of sequence reads were mapped to unique positions in the reference genome indicating the utility of ddRAD method to target unique regions in a genome. The mapping of reads to unique regions also ensured that the SNPs from duplicated or paralogous regions are excluded for further analysis.

Typically, the SNPs are distributed throughout a genome and the average frequency of distribution of SNPs has been found to be between $100 \mathrm{nt}$ to $500 \mathrm{nt}$. In the present study, the occurrence of $93 \%$ of hypervariable regions (hotspots) of SNPs in the coding regions of Brassica juncea with SNPs distributed in upstream, downstream and in the intergenic regions of the coding regions. Most of these hypervariable regions had SNP frequency of less than $10 \mathrm{nt}$. Further, the detection of 40 genes/coding sequences in the chromosomal regions harbouring SNP hotspots might point to a possible regulatory role of these SNPs in the expression of these genes. Although, few previous studies have reported such SNP hotspots in repetitive regions mostly due to errors of DNA polymerase resulting in strand slippage and unequal exchange [32,33] or due to presence of mutational hotspots or recombination hotspots [34]. The SNP hotspots along each chromosome were found to be distributed randomly and the number of SNPs involved in such hotspots ranged from four to eleven within $50 \mathrm{nt}$ of chromosomal region in the current study. The role of high selection pressure due to environmental stress could lead to the accumulation of mutated allelic sites in the genic regions that improve survival of the crop under adverse environmental conditions [35, 36].

The high proportion (97\%) of functional SNPs across a set of highly diverse genotypes indicated the accuracy of ddRAD technology to invariably target same locus across different individuals during the library preparation and partly due to the improved bioinformatics tools for sequence mapping and SNPs identification for complex and polyploidy crops. The SNPs identified through RAD-seq and its modifications in the previous studies have shown similar functionality levels in other crops as well $[37,38]$. The biallelic data obtained from a subset of 61 functional SNPs in the present study was able to group diverse $B$. juncea genotypes into two major clusters- Indian and Exotic (European) genepool. The diversity and clustering results are in agreement with the previous studies based on SSR and other marker system. The SNP-based diversity analysis also concluded that a small subset of uniformly distributed SNPs would be highly useful for various genetic analyses.

The morphological characterization of six traits revealed very interesting patterns on correlation matrix. The bimodal distribution for DTF and DTM upon combined analysis of all the genotypes indicated that these two traits are controlled by different set of genes in Indian and European genepools. The European genepool has traditionally been domesticated under lowtemperature short-day conditions while the Indian genepool is more conducive for sowing in moderate to low temperature conditions found mostly in the northwestern plains of Indian subcontinent. The hypothesis of different set of genes controlling DTF and DTM in Indian and European genepools got further strengthened upon getting a unimodal distribution for DTF and DTM in correlation matrices individually for Indian and European genepools. However, the detailed interaction between the genotype and phenotype could be studied by undertaking QTL analysis and other genetic analyses.

In the present study, a common subset of 61 SNPs was used for diversity, population structure and association analyses. For diversity and population structure analyses, the subset of SNPs was able to group 80 genotypes into two distinct clusters, each over-represented by genotypes either from Indian and European (exotic) genepools; which indicated the usefulness of 


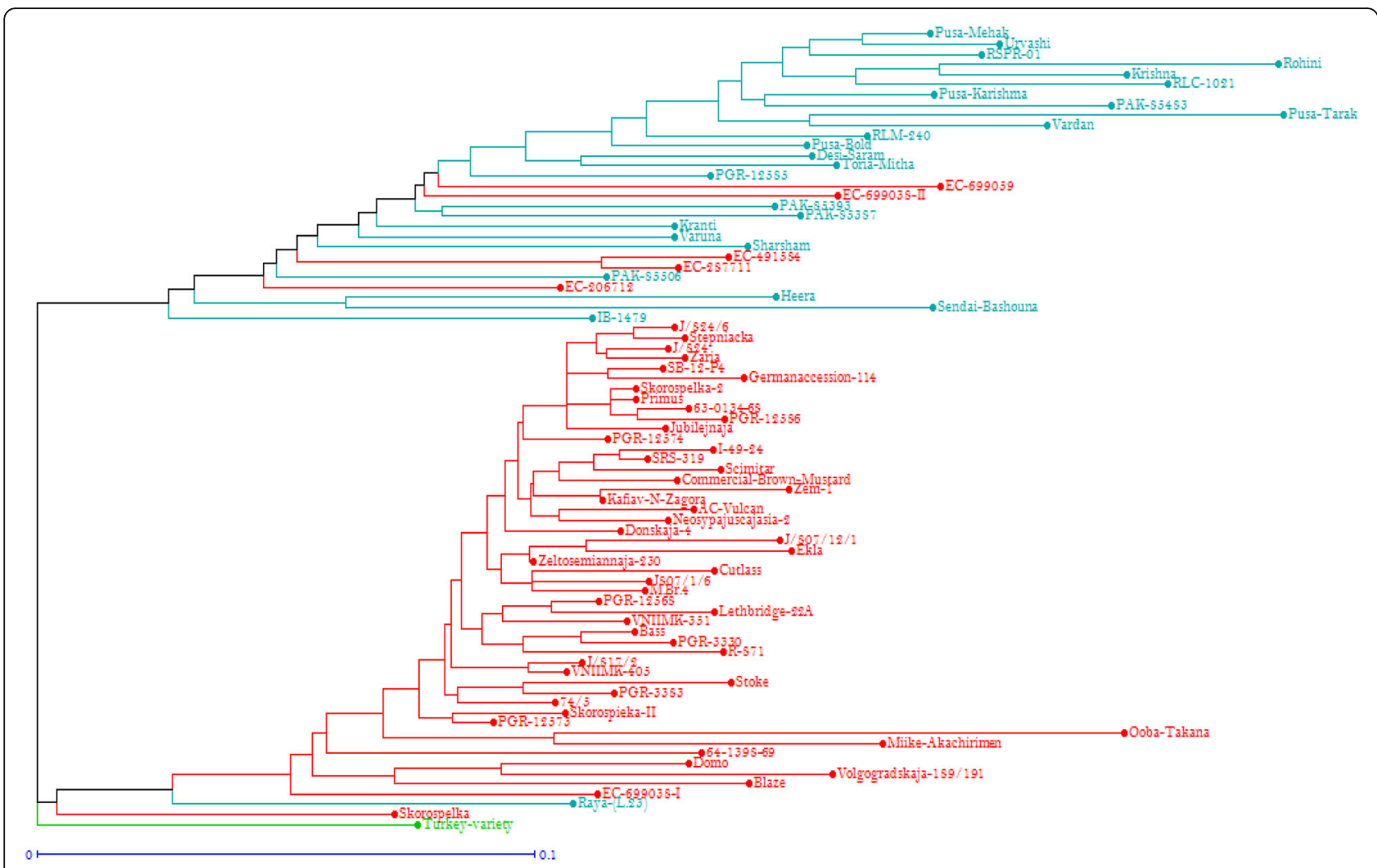

Fig. 3 UPGMA dendrogram showing genetic relationship among 80 different Brassica juncea genotypes. Blue labeled genotypes are of Indian subcontinent, red labeled genotypes are of exotic origin and green labeled genotype is from Turkey

strategy involving the usage of sparse but uniformly localised SNPs for various genetic analyses.

A subset of SNPs representing all chromosomal regions of $B$. juncea was used to identify significant marker-trait associations. The association analysis using SNP subset was able to localize genes for various agromorphological trait on different chromosomes, identifying genome regions for undertaking fine mapping of traits/genomic regions with large number of molecular markers. A majority of SNPs identified associations with multiple traits thus essentially indicating either the clustering of genes for multiple traits or involvement of same set of genes regulating multiple traits in the same genomic regions. Among these traits, DTF and DTM had invariably common $\mathrm{SNP} /$ genomic region associated with them, thus implying that the genes for these two traits are clustered together and/or likely have correlated/coordinated expression of genes. A recent study, using $\mathrm{F}_{2}$ mapping population, in Brassica napus has also identified the co-localisation of QTLs (and eQTLs) for flowering time and various growth-related morphological traits to a common genomic region of chromosome A10 [39]. In another study, QTLs for various quality and nutritional traits were again mapped to common regions of a genetic map of a DH (double haploids) mapping population in Brassica napus [40]. Such clusters of QTLs for multiple traits were also reported using chromosome segment substitution lines (cssls) in Brassica rapa [41]. High correlation between DTF and DTM traits, in the current study, among both Indian and European genepools also indicate the high probability of association of common genomic regions (and SNPs) for both the traits as reported in one of the earlier study as well [42].

The presence of a common ancestral genome between three polyploidy species led to the identification and comparison of association analysis results. In the current study, the associations for DTF were mapped to A- and B- genome chromosomes. Similarly genes for flowering time have been identified on both A- and B- subgenomes of B. juncea [43]. Two highly significant associations for DTF were identified each at 6.8 MB (A06_6796237) and 23.4 MB (A06_ 23478761) in the current study are in agreement with the results for flowering time related (FTR) genes. Thirty three flowering time related (FTR) genes were identified on chromosome A06 between 7.2 MB - 21.6 MB regions using transcriptome analysis [44]. The association analysis results of the current study indicated that a subset of sparse but uniformly localised SNPs would be highly useful to demarcate genomic regions for traits of interest. 
Table 5 Summary of marker-trait associations using SNP markers

\begin{tabular}{|c|c|c|c|c|c|}
\hline S. No. & Trait & Marker & Chromosome & $p$ value & $r^{2}$ \\
\hline 1. & DTF & A01_1808370 & $\mathrm{A} 01$ & $7.59 \mathrm{E}-15$ & 0.52 \\
\hline 2. & DTM & A01_1808370 & A01 & $2.69 \mathrm{E}-13$ & 0.48 \\
\hline 3. & SL & A01_1808370 & $\mathrm{A} 01$ & $1.04 \mathrm{E}-10$ & 0.41 \\
\hline 4. & DTF & A01_6850903 & A01 & 2.82E-08 & 0.30 \\
\hline 5. & DTM & A01_6850903 & $\mathrm{A} 01$ & 4.20E-07 & 0.26 \\
\hline 6. & DTF & A02_24062658 & $\mathrm{A} 02$ & 2.96E-06 & 0.22 \\
\hline 7. & DTM & A02_24062658 & $\mathrm{A} 02$ & 7.58E-06 & 0.20 \\
\hline 8. & SL & A03_20651981 & $\mathrm{A} 03$ & 1.53E-09 & 0.38 \\
\hline 9. & DTM & A03_20651981 & $\mathrm{A} 03$ & 4.59E-07 & 0.28 \\
\hline 10. & DTF & A03_20651981 & $\mathrm{A} 03$ & 7.37E-07 & 0.29 \\
\hline 11. & DTF & A03_8547652 & $\mathrm{A} 03$ & 4.16E-14 & 0.49 \\
\hline 12. & DTM & A03_8547652 & A03 & 1.05E-12 & 0.46 \\
\hline 13. & DTF & A04_17601178 & $\mathrm{A} 04$ & $2.27 \mathrm{E}-07$ & 0.35 \\
\hline 14. & SL & A04_17601178 & $\mathrm{A} 04$ & $3.62 \mathrm{E}-06$ & 0.27 \\
\hline 15. & DTF & A06_23478761 & A06 & $6.03 E-06$ & 0.26 \\
\hline 16. & SL & A06_23478761 & A06 & $7.11 \mathrm{E}-06$ & 0.26 \\
\hline 17. & DTM & A06_6796237 & A06 & $8.28 \mathrm{E}-16$ & 0.54 \\
\hline 18. & DTF & A06_6796237 & A06 & $1.94 \mathrm{E}-15$ & 0.54 \\
\hline 19. & SL & A06_6796237 & A06 & 4.05E-12 & 0.45 \\
\hline 20. & DTF & A07_11271 & $\mathrm{A} 07$ & 4.34E-06 & 0.26 \\
\hline 21. & $S L$ & A08_26316831 & $\mathrm{A} 08$ & $9.60 \mathrm{E}-08$ & 0.31 \\
\hline 22. & DTF & A08_26316831 & A08 & $1.31 \mathrm{E}-07$ & 0.31 \\
\hline 23. & DTM & A08_26316831 & A08 & $5.01 \mathrm{E}-07$ & 0.28 \\
\hline 24. & DTF & B01_31415063 & B01 & $5.26 \mathrm{E}-09$ & 0.36 \\
\hline 25. & DTM & B01_31415063 & B01 & $3.40 \mathrm{E}-07$ & 0.30 \\
\hline 26. & $S L$ & B01_31415063 & B01 & $5.96 \mathrm{E}-06$ & 0.25 \\
\hline 27. & SPS & B02_1692560 & B02 & $126 \mathrm{E}-07$ & 0.89 \\
\hline 28. & DTF & B02_14715231 & B02 & $2.10 \mathrm{E}-07$ & 0.30 \\
\hline 29. & SL & B02_14715231 & B02 & $6.71 E-06$ & 0.24 \\
\hline 30. & DTF & B04_20687623 & B04 & $4.02 \mathrm{E}-12$ & 0.45 \\
\hline 31. & DTM & B04_20687623 & B04 & 1.30E-09 & 0.37 \\
\hline 32. & $S L$ & B04_20687623 & B04 & $1.74 \mathrm{E}-06$ & 0.27 \\
\hline 33. & $\mathrm{PH}$ & B04_20687623 & B04 & $7.18 \mathrm{E}-06$ & 0.26 \\
\hline 34. & DTF & B06_18644772 & B06 & $1.22 \mathrm{E}-14$ & 0.49 \\
\hline 35. & DTM & B06_18644772 & B06 & $2.79 \mathrm{E}-11$ & 0.39 \\
\hline 36. & $S L$ & B06_18644772 & B06 & $6.61 \mathrm{E}-08$ & 0.28 \\
\hline 37. & DTM & B06_9741730 & B06 & $1.15 \mathrm{E}-18$ & 0.60 \\
\hline 38. & DTF & B06_9741730 & B06 & $2.22 \mathrm{E}-16$ & 0.56 \\
\hline 39. & SL & B06_9741730 & B06 & 8.93E-11 & 0.42 \\
\hline 40. & SL & B08_189749 & B08 & $1.29 \mathrm{E}-07$ & 0.31 \\
\hline 41. & DTF & B08_189749 & B08 & 8.26E-07 & 0.28 \\
\hline 42. & TSW & B08_189749 & B08 & 1.83E-06 & 0.30 \\
\hline 43. & DTF & B08_7286923 & B08 & $5.76 \mathrm{E}-17$ & 0.56 \\
\hline
\end{tabular}

Table 5 Summary of marker-trait associations using SNP markers (Continued)

\begin{tabular}{llllll}
\hline S. No. & Trait & Marker & Chromosome & $p$ value & $r^{2}$ \\
\hline 44. & DTM & B08_7286923 & B08 & $4.71 \mathrm{E}-15$ & 0.51 \\
45. & SL & B08_7286923 & B08 & 8.20E-09 & 0.34 \\
\hline
\end{tabular}

\section{Conclusion}

This is the first report of use of ddRAD-seq for the development of SNPs in Brassica juncea. The SNPs were developed initially from sequence comparison of six genotypes only; however the SNPs were found to be functional when tested on a diverse set of genotypes. The SNPs used for association analysis were also found to be significantly associated with six morphological traits. Given the fact that Brassica juncea has narrow genetic base, the SNPs identified in the current study would form an excellent source for various genetic studies including linkage mapping, fine mapping and association analysis.

\section{Methods \\ Plant material and DNA extraction}

A set of six $B$. juncea genotypes (three each from Indian and Exotic germplasm) were selected for use in ddRAD library preparation. Pusa Tarak (BJI-1), Urvashi (BJI-2) and RSPR-O1 (BJI-3) were selected from Indian genepool and Zem 1 (BJE-1), Donskaja IV (BJE-2) and EC287711 (BJE-3) were selected from European (exotic) genepool. Seeds were procured from (Dr. Deepak Pental) University of Delhi (South Campus), India and National Bureau of Plant Genetic Resources, New Delhi, India. SNP genotyping was performed on 80 diverse $B$. juncea genotypes that were procured from Plant Gene Resources, Agriculture and Agri-Food, Canada and Genetics \& Plant Breeding Department, SKUAST-Jammu, India (Additional file 1:Table-S4). Total genomic DNA was isolated using modified SGS buffer method [45] and purified DNA was used for dd-RAD library preparation.

\section{Morphological data evaluation and statistical analysis}

The phenotypic data of diverse core set of $B$. juncea was also recorded from two different locations in 2015-16 and 2016-17. The data were collected for six traits: days to flowering (DTF- number of days from sowing to the date when $50 \%$ of the plants had their flower opened in each plot), days to maturity (DTM- number of days from sowing to the date when pods on $75 \%$ of the plants in each plot were turned browned), plant height ( $\mathrm{PH}-$ in meters), siliqua length (SL- in centimeters), seeds per siliqua (SPS- average number of the seeds present in single pod/siliqua) and thousand seed weight (TSW- weight in grams of the 1000 seeds collected in random). The traits value of each genotype was defined as an average 
of two replicates in the same location. The correlation coefficients between traits were determined using Student's t-test and the variance components were also calculated.

\section{ddRAD library development and NGS sequencing}

The ddRAD-seq protocol $[25,46]$ was used with slight modification for the construction of sequence-barcoded reduced representation libraries (RRLs) from six Brassica juncea genotypes. For ddRAD library preparation, ten microgram of purified DNA was digested to completion with Mse I and Sac I. The digested DNA was separated on $0.8 \%$ agarose gel; fragments between 300 and $400 \mathrm{bp}$ were gel excised and eluted. The eluted and purified DNA was then end repaired, short dA-tail was attached and ligated with the adapters following manufacturer protocol. The ligated DNA was amplified using PCR to enrich and add the Illumina specific index and flow cell annealing sequences to the fragmented DNA. For each six genotypes, six different index sequences were used so at to facilitate the process of pooling. All six DNA samples were normalized to a final concentration of $50 \mathrm{ng} / \mu \mathrm{l}$ and pooled to reach a final volume of $300 \mu$ to generate a reduced representation library. The pooled dd-RAD library was then sequenced using Illumina HiSeq 2000 to generate $100 \mathrm{bp}$ paired-end reads.

\section{Sequence preprocessing and SNP detection}

The ddRAD-seq reads obtained after sequencing were bioinformatically analyzed using CLC Genomics Software in order to obtain a high quality SNP set. The paired end sequencing reads were subjected to a series of steps (demultiplexing, trimming, mapping with reference genome, local realignment, SNPs detection and annotation with flanking sequences) through a pipeline. The following filtering scheme (Fig. 4) was used to maximize the retention of true genic polymorphic SNPs: (1) trimming of 13 bases from forward and 3 bases from reverse end, (2) mapping parameters were set to- mismatch cost: 2 , insertion cost: 3 , deletion cost: 3 , length fraction: 0.5 , similarity fraction: 0.95 and we have selected to perform local alignment instead of global alignment as it allows the ends to be left unaligned if there are many differences from the reference at the ends, (3) probabilistic SNP detection method was used for SNP detection from mapped reads with parameters- minimum coverage: 4 , variant probability: 98.00 and ploidy: 2 and (4) flanking sequence of $400 \mathrm{bp}$. For mapping of

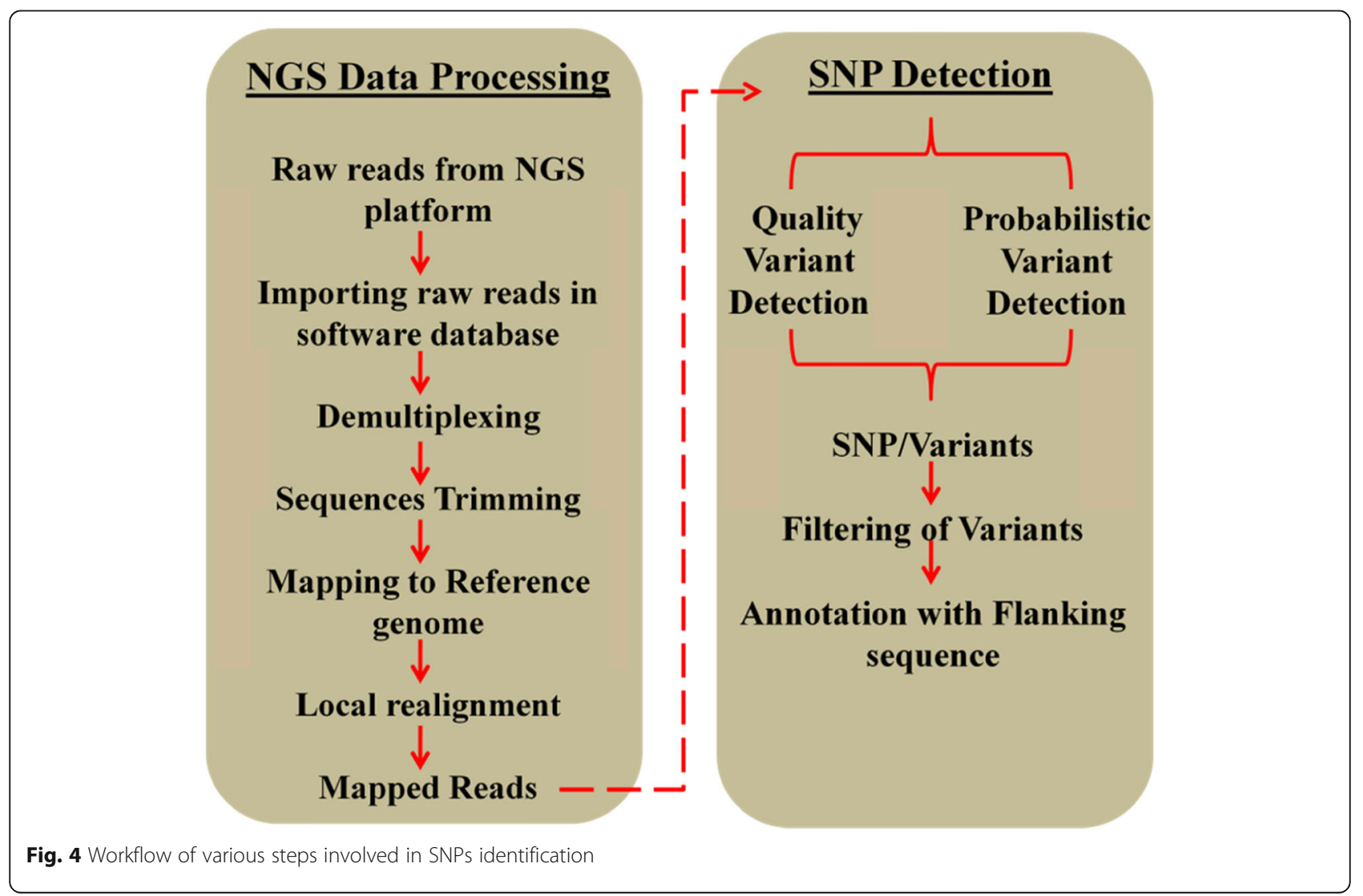


reads, Brassica juncea genome was used as a reference genome [47].

\section{Validation of SNPs and genotyping}

A subset of 61 SNP loci was selected with 3-4 SNPs from each chromosome and was validated across the diverse set of B. juncea. The sequences flanking each SNP were used to synthesize forward, reverse and $i P L E X$ universal extension primer using Agena CXassay design suite V2.0 software. The forward and reverse PCR primers were diluted to the concentration of $100 \mu \mathrm{M}$, while iPLEX universal extension primers were diluted to the concentration of $500 \mu \mathrm{M}$. The experimental procedure included- (1) multiplex PCR using forward and reverse primer, (2) SAP (Shrimp Alkaline Phosphatase) clean up reaction, (3) iPLEX extended reaction with the amplified product, (4) resin cleanup reaction to remove salts, (5) spotting of primer extended product on spectrochip and (6) spectro-chip detection using MALDI-TOF mass spectrometry. The genotype calls were evaluated through MassARRAY TYPER 4.0 software.

\section{Population and diversity analysis}

The SNP genotyping data were used for population structure and genetic diversity analyses [48] following Singh et al. [49]. The posterior probabilities $(q K)$ were estimated with 10,000 burn-ins followed by 100,000 iterations. For structure analysis, the diverse population was assumed to be following an admixture model and correlated allele frequencies with no prior population information. The structure analysis was performed with 5 replicates for each $K$ ranging from 1 to 5 . The $\Delta K$ was calculated using Structure Harvester software [50] to obtain an optimal value of $K$. The membership coefficient with a threshold of $70 \%$ for each replicate of structure analysis was used to generate a $\mathrm{Q}$ matrix using the software CLUMPP [51]; followed by plotting of Q matrix using DISTRUCT software [52]. The polymorphic information content (PIC) value and allele frequencies were calculated using Powermarker v3.51 [53]. The unweighted neighbor joining tree method was implemented in Darwin5 software [54] for constructing a phylogenetic tree; and the bootstrap value for this tree was determined by re-sampling loci at 1000 times.

\section{Gene identification and annotation using database}

Flanking sequence of SNPs/ hyper-variable regions were compared against the $B$. juncea database using BLASTX (cutoff E-value of $1 \mathrm{E}-10)$ to identify the corresponding sequences in the protein database [55].

\section{Association analysis}

Association analysis was performed by using the genotypic (SNPs) and phenotypic data of the diverse Brassica genotypes and population structure data ( $\mathrm{Q}$ matrix) by using TASSEL software [56]. Marker-trait association analysis was conducted using TASSEL 3.0 software along with the GLM procedure keeping significant threshold for the association at $P<0.01$.

\section{Supplementary information}

Supplementary information accompanies this paper at https://doi.org/10. 1186/s12870-019-2188-X.

\section{Additional file 1: Figure S1. Workflow design for SNPS/Nariants} detection in CLC Genomics Workbench (Red solid lines indicate input file; blue dotted lines indicate output file). Figure S2. Bioanalyser analysis of the prepared library (Blue peaks indicate ladder peaks and red peaks at 35 and 10,380 bp indicate internal standards). Table S3. Summary of ddRAD-sequence data for six genotypes. Table S4. Details of Brassica juncea genotypes used for association analysis.

\section{Abbreviations}

BJE: Brassica juncea Exotic; BJI: Brassica juncea Indian; ddRAD: double digestRestriction Associated DNA; DH: Double Haploids; DTF: Days to flowering; DTM: to maturity; GLM: Generalized Linear Model; LD: Linkage Disequilibrium; MALDI-TOF: Matrix-Assisted Laser Desorption/lonization-Time Of Flight; MAS: Molecular Assisted Selection; PCA: Principal Component Analysis; PH: Plant Height; PIC: Polymorphism Information Content; QTL: Quantitative Trait Loci; RRLs: Reduced Representation Libraries; SL: Siliqua Length; SLAFseq: Specific Locus Amplified Fragment Sequencing; SNPs: Single Nucleotide Polymorphisms; SPS: Seeds per Siliqua; SSRs: Simple Sequence Repeats;

TSW: Thousand Seed Weight

\section{Acknowledgments}

Not Applicable.

\section{Author's contributions}

RS design whole experiment; RS and JS performed bioinformatics analysis; RS, JS, SS and SMZ carried out genetic analyses; JS, VS, GS, IS and SKS designed and performed MassARRAY analysis; RS, JS, SKG and RKS wrote manuscript. All authors read and approved the manuscript.

\section{Funding}

The authors acknowledge the funds received as a research grant (BT/ PR3946/AGR/2/839/2011 from 2013 to 2016) from Department of Biotechnology, Government of India, New Delhi.

\section{Availability of data and materials}

SNPs identified from six genotypes in this study have been submitted to the European Variation Archive at EMBL-EBI database under accession number PRJEB26751.

Ethics approval and consent to participate

- Not applicable.

Consent for publication

- Not applicable.

Competing interests

Authors declared that they have no competing interest.

\section{Author details}

${ }^{1}$ School of Biotechnology, Sher-e-Kashmir University of Agricultural Sciences and Technology of Jammu, Jammu, J\&K, India. ${ }^{2}$ JECRC University- Jaipur, Jaipur, Rajasthan, India. ${ }^{3}$ Human Genetics Research Group, School of Biotechnology, Shri Mata Vaishno Devi University, Katra, J\&K, India. ${ }^{4}$ Division of Plant Breeding and Genetics, Sher-e-Kashmir University of Agricultural Sciences and Technology of Kashmir, Jaipur, J\&K, India. ${ }^{5}$ Division of Plant Biotechnology, Sher-e-Kashmir University of Agricultural Sciences and Technology of Kashmir, Jammu, J\&K, India. 


\section{Received: 18 October 2019 Accepted: 5 December 2019} Published online: 30 December 2019

\section{References}

1. Dhaka N, Rout K, Yadava SK, Sodhi YS, Gupta V, Pental D, Pradhan AK. Genetic dissection of seed weight by QTL analysis and detection of allelic variation in Indian and east European gene pool lines of Brassica juncea. Theor Appl Genet. 2017;130(2):293-307.

2. Yadava SK, Arumugam N, Mukhopadhyay A, Sodhi YS, Gupta V, Pental D, Pradhan AK. QTL mapping of yield-associated traits in Brassica juncea: metaanalysis and epistatic interactions using two different crosses between east European and Indian gene pool lines. Theor Appl Genet. 2012;125(7):155364

3. Pradhan AK, Sodhi YS, Mukhopadhyay A, Pental D. Heterosis breeding in Indian mustard (Brassica juncea L. Czern \& Cross): analysis of component characters contributing to heterosis for yield. Euphytica. 1993;69:219-29.

4. Lukens LN, Quijada PA, Udall J, Pires JC, Schranz ME, Osborn TC. Genome redundancy and plasticity within ancient and recent Brassica crop species. Biol J Linn Soc. 2004;82(4):665-74.

5. Srivastava A, Gupta V, Pental D, Pradhan AK. AFLP-based genetic diversity assessment amongst agronomically important natural and some newly synthesized lines of Brassica juncea. Theor Appl Genet. 2001;102:193-9.

6. Nordborg M, Weigel D. Next-generation genetics in plants. Nature. 2003; 456:720-3

7. Luo X, Ma C, Yue Y, Hu K, Li Y, Duan Z, et al. Unraveling the complex trait of harvest index in rapeseed (Brassica napus L.) with association mapping. BMC genomics. 2015;16(1):379.

8. Akhatar J, Banga SS. Genome-wide association mapping for grain yield components and root traits in Brassica juncea (L.) Czern \& Coss. Molecular Breeding. 2015;35(1):48

9. Dhaka N, Mukhopadhyay A, Paritosh K, Gupta V, Pental D, Pradhan AK Identification of genic SSRs and construction of a SSR-based linkage map in Brassica juncea. Euphytica. 2017;213(1):15.

10. Cai D, Xiao Y, Yang W, Ye W, Wang B, Younas M, Wu J, Liu K. Association mapping of six yield-related traits in rapeseed (Brassica napus L.). Theor Appl Genet. 2014;127(1):85-96.

11. Gyawali S, Harrington M, Durkin J, Horner K, Parkin IA, Hegedus DD, Bekkaoui D, Buchwaldt L. Microsatellite markers used for genome-wide association mapping of partial resistance to Sclerotinia sclerotiorum in a world collection of Brassica napus. Mol Breed. 2016;36(6):72.

12. Fu Y, Zhang D, Gleeson M, Zhang Y, Lin B, Hua S, Ding H, Frauen M, Li J, Qian W, Yu H. Analysis of QTL for seed oil content in Brassica napus by association mapping and QTL mapping. Euphytica. 2017;213(1):17.

13. Qu CM, Li SM, Duan XJ, Fan JH, Jia LD, Zhao HY, Lu K, Li JN, Xu XF, Wang R. Identification of candidate genes for seed glucosinolate content using association mapping in Brassica napus L. Genes. 2015;6(4):1215-29.

14. Li F, Chen B, Xu K, Gao G, Yan G, Qiao J, Li J, Li H, Li L, Xiao X, Zhang T. A genome-wide association study of plant height and primary branch number in rapeseed (Brassica napus). Plant Sci. 2016;242:169-77.

15. Luo X, Xue Z, Ma C, Hu K, Zeng Z, Dou S, Tu J, Shen J, Yi B, Fu T. Joint genome-wide association and transcriptome sequencing reveals a complex polygenic network underlying hypocotyl elongation in rapeseed (Brassica napus L.). Scientific Reports. 2017;7:41561.

16. Qu C, Jia L, Fu F, Zhao H, Lu K, Wei L, Xu X, Liang Y, Li S, Wang R, Li J. Genome-wide association mapping and Identification of candidate genes for fatty acid composition in Brassica napus L. using SNP markers. BMC genomics. 2017;18(1):232

17. Chao H, Raboanatahiry N, Wang X, Zhao W, Chen L, Guo L, Li B, Hou D, Pu S, Zhang L, Wang $H$. Genetic dissection of harvest index and related traits through genome-wide quantitative trait locus mapping in Brassica napus. Breed Sci. 2019:69(1):104-16.

18. Blanc G, Barakatm A, Guyot R, Cooke R, Delseny M. Extensive duplication and reshuffling in the Arabidopsis genome. Plant Cell. 2000;12(7):1093-101.

19. Schranz ME, Lysak MA, Mitchell-Olds T. The ABC's of comparative genomics in the Brassicaceae: building blocks of crucifer genomes. Trends Plant Science. 2006;11(11):535-42.

20. Yang TJ, Kim JS, Kwon SJ, Lim KB, Choi BS, Kim JA, Jin M, Park JY, Lim MH, Kim $\mathrm{H}$, et al. Sequence-level analysis of the diploidization process in the triplicated FLOWERING LOCUS C region of Brassica rapa. Plant Cell. 2006; 18(6):1339-47
21. Schirmer M, D'Amore R, ljaz UZ, Hall N, Quince C. Illumina error profiles: resolving fine-scale variation in metagenomic sequencing data. BMC Bioinformatics. 2016;17:12.

22. Gupta SK, Baek J, Carrasquilla-Garcia N, Penmetsa RV. Genome-wide polymorphism detection in peanut using next-generation restriction-siteassociated DNA (RAD) sequencing. Mol Breed. 2015;35(7):145.

23. Valdisser PAMR, Pappas GJ, Menezes IPP, Muller BSF, Pereira WJ, Vianello RP. SNP discovery in common bean by restriction associated DNA (RAD) sequencing for genetic diversity and population structure analysis. Mol Gen Genomics. 2016;11:1182-97.

24. Marrano A, Birolo G, Prazzoli ML, Lorenzi S, Valle G, Grando MS. SNPDiscovery by RAD-Sequencing in a Germplasm Collection of Wild and Cultivated Grapevines (V. vinifera L.). PloS one. 2017;12(1):e0170655.

25. Peterson BK, Weber JN, Kay EH, Fisher HS, Hoekstra HE. Double digest RADseq: an inexpensive method for de novo SNP discovery and genotyping in model and non-model species. PloS one. 7(5):e37135.

26. Carmichael SN, Bekaert M, Taggart JB, Christie HR, Bassett DI, Bron JE, Skuce PJ, Gharbi K, Skern-Mauritzen R, Sturm A. Identification of a sex-linked SNP marker in the salmon louse (Lepeophtheirus salmonis) using RAD sequencing. PLoS One. 2013;8(10):e77832.

27. Burford MO, Coyle K, Daniels HV, Labadie P, Reiskind MH, Roberts NB, Roberts RB, Schaff J, Vargo EL. Development of a universal double-digest RAD sequencing approach for a group of nonmodel, ecologically and economically important insect and fish taxa. Mol Ecol Resour. 2016;16(6): 1303-14.

28. Byers RL, Harker DB, Yourstone SM, Maughan PJ, Udall JA. Development and mapping of SNP assays in allotetraploid cotton. Theor Appl Genet. 2012; 124(7):1201-14

29. Yang GQ, Chen YM, Wang JP, Guo C, Zhao L, Wang XY, Guo Y, Li L, Li DZ, Guo ZH. Development of a universal and simplified ddRAD library preparation approach for SNP discovery and genotyping in angiosperm plants. Plant Methods. 2016;12(1):39.

30. Chen X, Li X, Zhang B, Xu J, Wu Z, et al. Detection and genotyping of restriction fragment associated polymorphisms in polyploid crops with a pseudo-reference sequence: a case study in allotetraploid Brassica napus. BMC Genomics. 2013;14:346.

31. Ma JQ, Huang L, Ma CL, Jin JQ, Li CF, Wang RK, Zheng HK, Yao MZ, Chen L. Large-scale SNP discovery and genotyping for constructing a high-density genetic map of tea plant using specific-locus amplified fragment sequencing (SLAF-seq). PLoS One. 2015:10(6):e0128798.

32. Clayton $\mathrm{AL}$, Jackson $\mathrm{DG}$, Weiss RB, Dale C. Adaptation by deletogenic replication slippage in a nascent symbiont. Mol Biol Evol. 2016;33: 1957-66.

33. Zhou Q, Zhou C, Zheng W, Mason AS, Fan S, Wu C, Fu D, Huang Y. Genome-wide SNP markers based on SLAF-seq uncover breeding traces in rapeseed (Brassica napus L.). Frontiers Plant Sci. 2017;8:648.

34. Mercier R, Mézard C, Jenczewski E, Macaisne N, Grelon M. Themolecular biology of meiosis in plants. Annu Rev Plant. 2015;66:297-327.

35. Hayward AC, Tollenaere R, Dalton-Morgan J, Batley J. Molecular marker applications in plants. Methods Mol Biol. 2015;1245:13-27.

36. Weigel D, Nordborg M. Population genomics for understanding adaptation in wild plant species. Annu Rev Genet. 2015;49:315-38.

37. Wu X, Ren $C$, Joshi $T$, Vuong $T, X u$ D, Nguyen HT. SNP discovery by highthroughput sequencing in soybean. BMC Genomics. 2010;11:469.

38. Valdisser PAM, Pappas GJ, de Menezes IP, Müller BS, Pereira WJ, et al. SNP discovery in common bean by restriction-associated DNA (RAD) sequencing for genetic diversity and population structure analysis. Mol Gen Genomics. 2016;291(3):1277-91.

39. Li R, Jeong K, Davis JT, et al. Integrated QTL and eQTL mapping provides insights and candidate genes for fatty acid composition, flowering time, and growth traits in a F2 population of a novel synthetic allopolyploid Brassica napus. Front Plant Sci. 2018:9:1632.

40. Fattahi F, Fakheri BA, Solouki M, Möllers C, Rezaizad A. Mapping QTL Controlling agronomic traits in a doubled haploid population of winter oilseed rape (Brassica napus L.). J Genet. 2018;97(5):1389-406.

41. Li X, Wang W, Wang Z, Li K, Lim YP, Piao Z. Construction of chromosome segment substitution lines enables QTL mapping for flowering and morphological traits in Brassica rapa. Front Plant Sci. 2015:6:432.

42. Lv H, Wang Q, Liu X, Han F, Fang Z, Yang L, et al. Whole-genome mapping reveals novel QTL clusters associated with main agronomic traits of cabbage (Brassica oleracea var. capitata L.). Frontiers plant sci. 2016;7:989. 
43. Zhao N, Liu C, Meng Y, Hu Z, Zhang M, Yang J. Identification of flowering regulatory genes in allopolyploid Brassica juncea. Horticultural Plant J. 2019; 5(3):109-19.

44. Jian H, Zhang A, Ma J, Wang T, Yang B, Shuang LS, Liu L. Joint QTL mapping and transcriptome sequencing analysis reveal candidate flowering time genes in Brassica napus. BMC Genomics. 2019;20(1):21.

45. Sudan J, Raina M, Singh R, Mustafiz A, Kumari S. A modified protocol for high-quality DNA extraction from seeds rich in secondary compounds. J Crop Improv. 2017;31(5):637-47

46. Yang GQ, Chen YM, Wang JP, Guo C, Zhao L, Wang XY, Guo Y, Li L, Li DZ, Guo ZH. Development of a universal and simplified ddRAD library preparation approach for SNP discovery and genotyping in angiosperm plants. Plant Methods. 2016;12(1):39.

47. Yang J, Liu D, Wang X, Ji C, Cheng F, Liu B, Hu Z, Chen S, et al. The genome sequence of allopolyploid Brassica juncea and analysis of differential homoeolog gene expression influencing selection. Nat Genet. 2016;48(10): 1225-32.

48. Pritchard JK, Stephens M, Donnelly P. Inference of population structure using multilocus genotype data. Genetics. 2000;155(2):945-59.

49. Singh R, Bollina V, Higgins EE, Clarke WE, Eynck C, Sidebottom C, Gugel R, Snowdon R, Parkin IA. Single-nucleotide polymorphism identification and genotyping in Camelina sativa. Mol Breed. 2015;35(1):35.

50. Earl DA. STRUCTURE HARVESTER: a website and program for visualizing STRUCTURE output and implementing the Evanno method. Conserv Genet Resour. 2012;4(2):359-61.

51. Jakobsson M, Rosenberg NA. CLUMPP: a cluster matching and permutation program for dealing with label switching and multimodality in analysis of population structure. Bioinformatics. 2007;23(14):1801-6.

52. Rosenberg NA. DISTRUCT: a program for the graphical display of population structure. Mol Ecol Notes. 2004;4(1):137-8.

53. Liu K, Muse SV. PowerMarker: an integrated analysis environment for genetic marker analysis. Bioinformatics. 2005;21(9):2128-9.

54. Perrier X, Jacquemoud-Collet JP. 2006. DARwin software http://darwin.cirad. fr/darwin.

55. Liu S, Zhou Z, Lu J, Sun F, Wang S, Liu H, Jiang Y, Kucuktas H, Kaltenboeck $L$, Peatman E, Liu Z. Generation of genome-scale gene-associated SNPs in catfish for the construction of a high-density SNP array. BMC Genomics. 2011;12(1):53.

56. Bradbury PJ, Zhang Z, Kroon DE, Casstevens TM, Ramdoss Y, Buckler ES. TASSEL: software for association mapping of complex traits in diverse samples. Bioinformatics. 2007;23(19):2633-5.

\section{Publisher's Note}

Springer Nature remains neutral with regard to jurisdictional claims in published maps and institutional affiliations.

Ready to submit your research? Choose BMC and benefit from:

- fast, convenient online submission

- thorough peer review by experienced researchers in your field

- rapid publication on acceptance

- support for research data, including large and complex data types

- gold Open Access which fosters wider collaboration and increased citations

- maximum visibility for your research: over $100 \mathrm{M}$ website views per year

At $\mathrm{BMC}$, research is always in progress.

Learn more biomedcentral.com/submissions 